\title{
USING OF ELECTROCHEMICAL METHODS FOR STUDYING OF METALLOTHIONEIN CONTENT IN THE HUMAN BLOOD SERUM OF A PATIENT POISONED BY LEAD AND TREATED BY PLATINUM
}

\author{
Jitka Petrlováa, Ondřej Blaštík ${ }^{\mathrm{a}}$, Richard Průša ${ }^{\mathrm{b}}$, Jiří Kukačka ${ }^{\mathrm{b}}$, David Potěšili ${ }^{\mathrm{a}, \mathrm{c}}$, \\ Radka Mikelováa ${ }^{a}$ Vojtěch Adamª, Josef Zehnálek ${ }^{\mathrm{a}}$, René Kizek ${ }^{\mathrm{a}}$
}

\author{
a Department of Chemistry and Biochemistry, Faculty of Agronomy, Mendel University of Agriculture and Forestry, \\ Zemědèlská 1, CZ-613 00 Brno, Czech Republic \\ ${ }^{b}$ Department of Clinical Biochemistry and Pathobiochemistry, $2^{\text {nd }}$ Faculty of Medicine, Charles University, VÚvalu 84, \\ CZ-150 06 Praha 5, Czech Republic \\ c Department of Analytical Chemistry, Faculty of Science, Masaryk University, Kotlářská 37, CZ-611 37 Brno, Czech \\ Republic \\ e-mail:kizek@sci.muni.cz
}

Received: June 10, 2005; Accepted: September 25, 2005

Key words: Metallothionein/Brdicka reaction/Peak H/Catalytic hydrogen reaction/Cancer/Lead/Differential pulse voltammetry/Adsorptive stripping voltammetry

Metallothioneins belong to the group of intracellular, high molecular and cysteine-rich proteins whose content increase with increasing concentration of a heavy metal. Here we applied the adsorptive transfer stripping differential pulse voltammetry Brdicka reaction for the determination of metallothionein in human blood serum of patient poisoned by lead and/or treated by platinum. The increased metallothionein concentrations in both cases were observed.

\section{INTRODUCTION}

Metallothionein (MT) belongs to the group of intracellular, high molecular and cysteine-rich proteins with molecular weight from 6 to $10 \mathrm{kDa}$ (ref. ${ }^{1}$ ). The MT was discovered in 1957, when Margoshes and Valee isolated it from horse kidney ${ }^{2}$. It is known that aromatic amino acids are not present in the MT molecule and twenty cysteines usually occur in its primary sequence at these repetitions: Cys-X-Cys, Cys-Cys-X-Cys-Cys, Cys-X-Cys-Cys, where X represents other aminoacid than cysteine ${ }^{1,3}$. MTs consist of two binding domains $(\alpha, \beta)$ that are assembled from cysteine clusters. Cysteine sulfhydryl groups participate in covalent bindings with heavy metals. The N-terminal part of the protein is marked as $\alpha$-domain, which has three binding places for divalent ions. $\beta$-Domain (C-terminal part) has the ability to bind four divalent ions of heavy metals. Moreover a group of human metallothioneins such as MT1, MT2, MT3 and MT4 has been described (Table 1).

Number of analytical techniques including electrochemistry ${ }^{4-8}$ is used for the determination of MT. Many authors have been giving attention to electrochemical determination and study of MT for more than 20 years $^{9-12}$. In addition, more than 70 years ago Brdicka discovered the catalytic evolution of hydrogen in the presence of cobalt(III) solution and of proteins ${ }^{13-16}$. This reaction has been intensively using for electrochemical determination of proteins and has been modified by number of authors $^{17-19}$.
The aim of this work was to use adsorptive transfer stripping (AdTS) differential pulse voltammetry (DPV) Brdicka reaction for studying of metallothionein content in the human blood serum of a patient poisoned by lead and treated by platinum.

\section{MATERIAL AND METHODS}

\section{Chemicals}

Sodium chloride and other used chemicals were purchased from Sigma Aldrich. The stock standard solutions of MT at $10 \mu \mathrm{g} / \mathrm{ml}$ was prepared by ACS water (SigmaAldrich, USA) and stored in the dark at $-20^{\circ} \mathrm{C}$. Working standard solutions were prepared daily by dilution of the stock solutions. The $\mathrm{pH}$ value was measured using WTW inoLab Level 3 with terminal Level 3 (Weilheim, Germany), controlled by personal computer program (MultiLab Pilot; Weilheim, Germany). The $\mathrm{pH}$-electrode (SenTix- H, pH 0-14/3M KCl) was regularly calibrated by set of WTW buffers (Weilheim, Germany).

\section{Human blood serum samples}

Human blood serum samples were obtained from the Department of Clinical Biochemistry and Pathobiochemistry, $2^{\text {nd }}$ Faculty of Medicine Charles University, Czech Republic. The samples were prepared by heat treatment and solvent precipitation. Briefly, the samples were kept at $99{ }^{\circ} \mathrm{C}$ in a thermomixer (Eppendorf 5430, USA) for 15 min with occasional stirring, and then cooled to 
$4{ }^{\circ} \mathrm{C}$. The denatured homogenates were centrifuged at $4{ }^{\circ} \mathrm{C}, 15000 \mathrm{~g}$ for $30 \mathrm{~min}$. (Eppendorf 5402, USA). Heat treatment and solvent precipitation effectively denature and remove high molecular weight proteins out from samples $^{19,20}$. Determination of MT in the human blood serum samples was performed by optimised AdTS DPV Brdicka reaction. Analysed sample volume was $5 \mu$ l.

\section{Electrochemical measurements}

Electrochemical measurements were performed with AUTOLAB Analyser (EcoChemie, Netherlands) connected to VA-Stand 663 (Metrohm, Switzerland), using a standard cell with three electrodes. The working electrode was a hanging mercury drop electrode (HMDE) with a drop area of $0.4 \mathrm{~mm}^{2}$. The reference electrode was an $\mathrm{Ag} /$ $\mathrm{AgCl} / 3 \mathrm{M} \mathrm{KCl}$ electrode and the auxiliary electrode was a graphite electrode. The supporting electrolyte was prepared by mixing buffer components except sodium chloride. For smoothing and baseline correction the software GPES 4.4 supplied by EcoChemie was employed.

\section{AdTS DPV Brdicka reaction of MT}

The Brdicka supporting electrolyte containing $1 \mathrm{mM}$ $\mathrm{Co}\left(\mathrm{NH}_{3}\right)_{6} \mathrm{Cl}_{3}$ and $1 \mathrm{M}$ ammonia buffer $\left(\mathrm{NH}_{3}(\mathrm{aq})+\right.$ $\mathrm{NH}_{4} \mathrm{Cl}, \mathrm{pH}=9.6$ ) was used; surface-active agent was not added. AdTS DPV Brdicka reaction parameters were as follows: an initial potential of $-0.35 \mathrm{~V}$, an end potential $-1.6 \mathrm{~V}$, a modulation time $0.057 \mathrm{~s}$, a time interval $0.2 \mathrm{~s}$, a step potential of $1.05 \mathrm{mV} / \mathrm{s}$, a modulation amplitude of
$250 \mathrm{mV}, \mathrm{E}_{\mathrm{ads}}=0 \mathrm{~V}$. Temperature of supporting electrolyte was tested ${ }^{20}$.

\section{RESULTS AND DISCUSSION}

Brdicka discovered protein catalysed hydrogen evolution signals more than 70 years ago ${ }^{21}$. In addition Brdicka found out that the hydrogen evolution could be used for diagnostic of tumour diseases ${ }^{22,23}$. On the other hand this technique has been replaced by new analytical techniques such electrophoresis, chromatography coupled with different kind of detectors in clinical medicine. Therefore we were interested in the issue if Brdicka reaction could be used in clinical lab nowadays. Recently new approaches such as adsorptive transfer stripping technique or modification of a surface of working electrode by a high- and/or low-molecular compound (Fig. 1) used for improvement of selectivity of Brdicka reaction has been described ${ }^{24,25,26}$. If the authors used the adsorptive transfer stripping technique in combination with Brdicka reaction, the sensitive determination of proteins was reached ${ }^{27,20}$.

Here we wanted to analyse the human blood serum samples of a patient poisoned by lead. To be specific, a 11-year-old girl was referred to the hospital by her general practitioner because of abdominal pain, vomiting, dark colour of tongue, low intake of fluid and food, and abnormal laboratory results (bilirubin $55 \mu \mathrm{mol} / 1$, AST $2.94 \mu \mathrm{kat} / 1$, ALT $3.46 \mu \mathrm{kat} / \mathrm{l}$, haemoglobin $86 \mathrm{~g} / 1$ ). Blood film, which

Table 1. The biochemical properties of human metallothioneins

\begin{tabular}{|c|c|c|c|c|}
\hline $\begin{array}{c}\text { Metallothionein } \\
\text { name }^{1}\end{array}$ & $\begin{array}{l}\text { Number of amino } \\
\text { acids }\end{array}$ & Molecular weight & Theoretical pI & Swiss-Prot number ${ }^{2}$ \\
\hline MT1A & 61 & 6133.2 & 8.38 & P04731 \\
\hline MT1B & 61 & 6115.3 & 8.47 & P07438 \\
\hline MT1E & 61 & 6014.1 & 8.38 & P04732 \\
\hline MT1F & 61 & 6086.2 & 8.23 & P04733 \\
\hline MT1G & 61 & 6070.2 & 8.38 & P13640 \\
\hline MT1H & 61 & 6039.2 & 8.49 & P80294 \\
\hline MT1I & 61 & 6040.2 & 8.38 & P80295 \\
\hline MT1K & 62 & 6141.3 & 8.38 & P80296 \\
\hline MT1L & 61 & 6068.2 & 8.38 & P80297 \\
\hline MT1R & 61 & 6062.2 & 8.38 & Q93083 \\
\hline MT2 & 61 & 6042.1 & 8.23 & P02795 \\
\hline MT3 & 68 & 6926.9 & 4.79 & $\mathrm{P} 25713$ \\
\hline MT4 & 62 & 6418.7 & 8.38 & P47944 \\
\hline
\end{tabular}

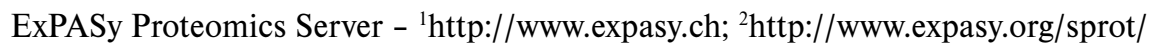


1

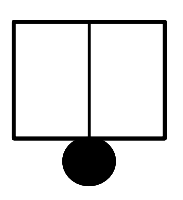

HMDE
2

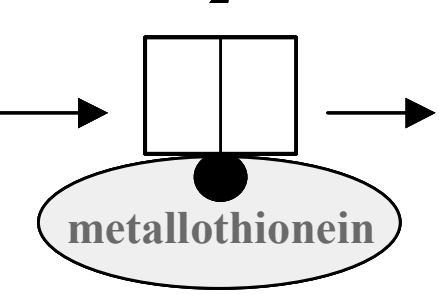

3

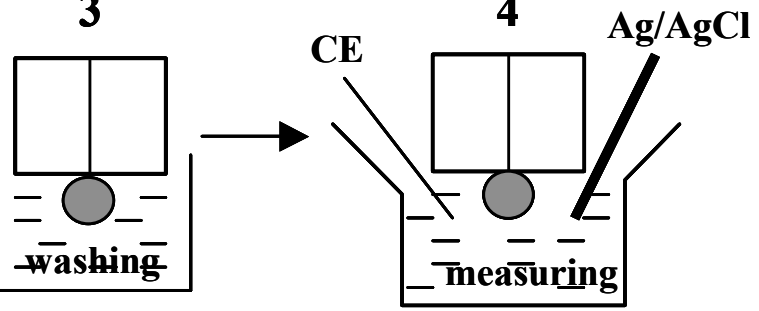

Fig. 1. Scheme of adsorptive transfer stripping technique; (1) renewing of the hanging mercury drop electrode (HMDE) surface; (2) adsorbing of MT in a drop solution onto the HMDE surface; (3) washing electrode in sodium chloride (0.5 M, pH 6.4) at open circuit; (4) measurement of MT by DPV Brdicka reaction.

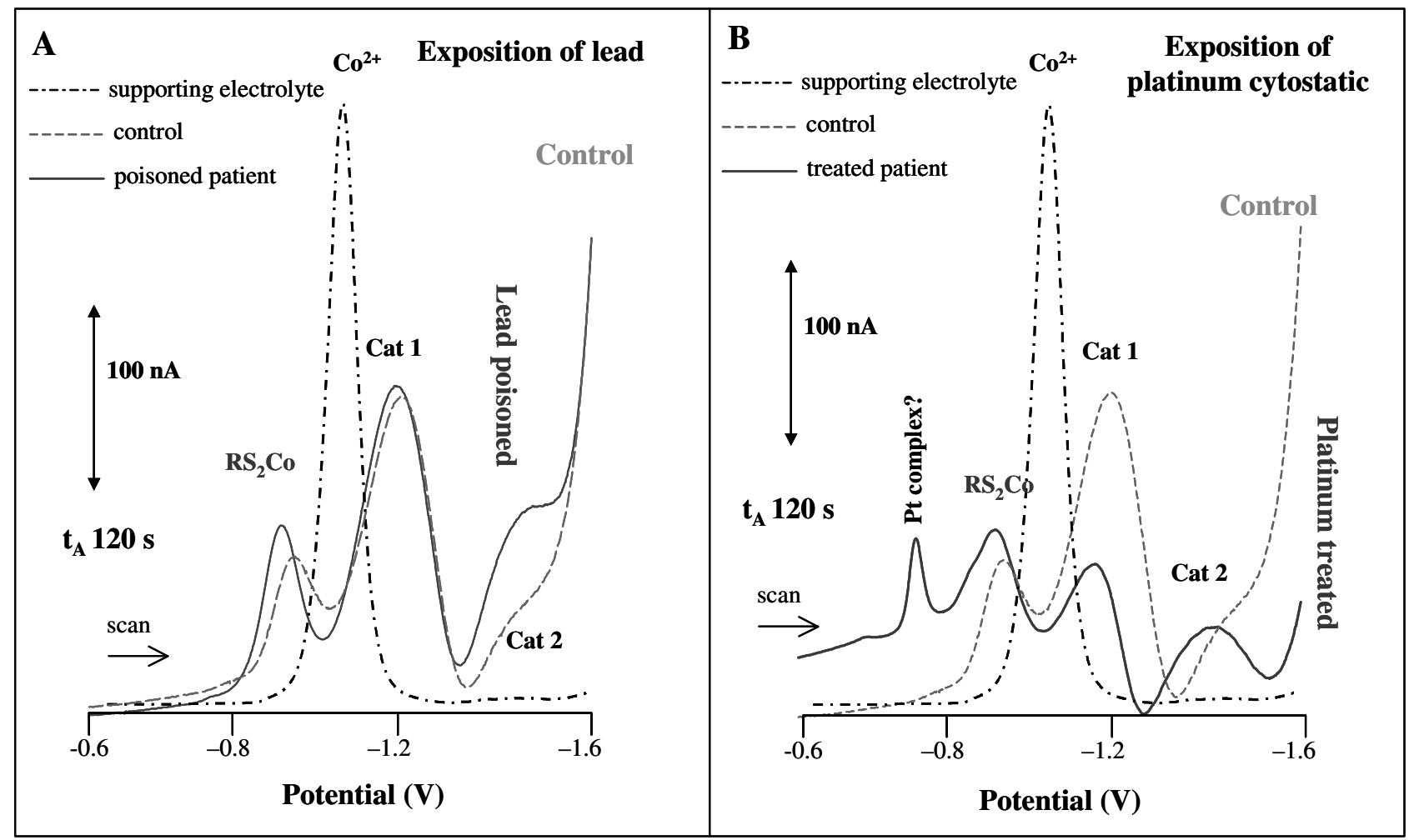

Fig. 2. AdTS DPV Brdicka reaction of blood serum of lead poisoned patient (A) and of platinum cytostatic treated patient (B). AdTS DPV Brdicka reaction parameters were as follows: an initial potential of $-0.35 \mathrm{~V}$, an end potential $-1.8 \mathrm{~V}$, a modulation time $0.057 \mathrm{~s}$, a time interval $0.2 \mathrm{~s}$, a step potential of $1.05 \mathrm{mV} / \mathrm{s}$, a modulation amplitude of $250 \mathrm{mV}, \mathrm{E}_{\text {ads }}=0 \mathrm{~V}$, the temperature of supporting electrolyte is $5^{\circ} \mathrm{C}$, the time of accumulation of MT is $120 \mathrm{~s}$, the concentration of $\mathrm{Co}\left(\mathrm{NH}_{3}\right)_{6} \mathrm{Cl}_{3}$ is $1 \mathrm{mM}$. The AdTS DPV signals i) of reduction of $\mathrm{Co}(\mathrm{II})$ contained in supporting electrolyte (dot-and-dash line); ii) of control (dashed line) and iii) of human blood serum of poisoned patient - first day of hospitalisation (continuous line) are shown.

exhibited basophilic stippling, is prompting for investigation of lead poisoning. The source of 6 months lead exposure was identified as tea from a ceramic tea pot with insufficient glassing (lead concentration was $45332 \mu \mathrm{g} / 1$ in tea after 30 minutes). It is common knowledge that heavy metals induce a synthesis of MT. Therefore we assumed that concentration of MT increased with rising amounts of lead in blood serum of the poisoned patient. The AdTS DPV signals i) of reduction of Co(II) contained in supporting electrolyte (dot-and-dash line); ii) of control (dashed line) and iii) of human blood serum of poisoned patient - first day of hospitalisation (continuous line) are shown in Fig. 2A. We observed three MT signals - $\mathrm{RS}_{2} \mathrm{Co}$ (complex of MT with Co(II)) and two catalytic signals (Cat1 and Cat2). We estimated that amount of MT in a blood serum of a healthy patient varies between 1 and $10 \mu \mathrm{M}(n=5)$. It clearly follows from the figure that Cat2 signal increased according to lead poisoning. Finally, it was found out that amount of MT in the human blood serum of the lead poisoned patient was more than $200 \mu \mathrm{M}$. 
Moreover MT concentration increase during treating of tumour diseases by platinum based cytostatics ${ }^{28}$. Therefore we determined the MT amounts in human blood serum of a patient, which has been treated by platinum complexes, by AdTS DPV Brdicka reaction. The increase in Cat 2 signal height of the treated blood serum corresponds to MT concentration of $150 \mu \mathrm{M}$ (Fig. 2B). That is why it is possible to assume that content of metallothionein was increased due to treatment by platinum based cytostatic. Moreover we observed a signal at potential of $-0.7 \mathrm{~V}$, which probably corresponds to complex between MT and platinum cytostatic. The experimental data indicate that it would be suitable to monitor the content of MT at patients treated by platinum based cytostatics for better recognising of platinum cytostatic resistance ${ }^{29}$.

\section{ACKNOWLEDGEMENT}

The work was supported by grants 8/2005 RASO, INCHEMBIOL 0021622412 and GAČR 525/04/P132.

\section{REFERENCES}

1. Kagi JHR, Schaffer A. (1988) Biochemistry of Metallothionein Biochemistry 27, 8509-15.

2. Margoshes M, Vallee BLA. (1957) A cadmium protein from equine kidney cortex. J Am Chem Soc 79, 4813-4.

3. Palmiter RD. (1994) Regulation of metallothionein gense by heavy metals appears to be mediated by a zinc-sensitive inhibitor that interacts with a constitutively active transcription fakctor, MTF-1. Proc Natl Acad Sci USA 91, 1219-23.

4. Kizek R, Trnkova L, Palecek E. (2001) Determination of metallothionein at the femtomole level by constant current stripping chronopotentiometry. Anal Chem 73, 4801-7.

5. Dabrio M, Rodríguez AR, Bordin G, Bebianno MJ, De Ley M, Šestáková I, Vašák M, Nordberg M. (2002) Recent developments in quantification methods for metallothionein. J Inorg Biochem 88 , 123-34.

6. Trnkova L, Kizek R, Vacek J. (2002) Catalytic signal of rabbit liver metallothionein on a mercury electrode: a combination of derivative chronopotentiometry with adsorptive transfer stripping. Bioelectrochemistry 56, 57-61.

7. Strouhal M, Kizek R, Vacek J, Trnkova L, Nemec M. (2003) Electrochemical study of heavy metals and metallothionein in yeast Yarrowia lipolytica. Bioelectrochemistry 60, 29-36.

8. Prusa R, Kizek R, Vacek J, Trnkova L, Zehnalek J. (2004) Study of relationship betwenn metallothionein and heavy metals by CPSA method. Clin Chem 50, A28-9.

9. Olafson RW, Sim RG. (1979) Electrochemical approach to quantitation and characterization of metallothioneins. Anal Biochem $100,343-51$

10. Olafson RW. (1988) Electrochemical characterization of metallothionein metal mercaptide complexes - Application of cyclic voltammetry to investigation of metalloproteins. Bioelectrochem Bioenerg 19, 111-25.

11. Olafson RW, Olsson PE. (1991) Electochemical detection of metallothionein. Methods Enzymol 205, 205-13.

12. Heyrovsky M. (2004) Early polarographic studies on proteins. Electroanalysis 16, 1067-73.

13. Brdicka R. (1933) Polarographic studies with the dropping mercury kathode. - Part XXXII. - activation of hydrogen in sulphydryl group of some thio-acids in cobalt salts solutions. Coll. Czech. Chem. Commun. 5, 148-64.

14. Brdicka R. (1933) Polarographic studies with the dropping mercury kathode. -Part XXXI. - a new test for proteins in the presence of cobalt salts in ammoniacal solutions of ammonium chloride. Coll Czech Chem Commun 5, 112-28.

15. Brdicka R. (1936) Polarographic studies with the dropping mercury kathode. -Part LXI. - the effect of buffer solutions on the reaction of proteins. Coll Czech Chem Commun. 8, 366-76.

16. Kolthoff IM, Yamashita K, Hie TB. (1975) Brdicka currents observed with bovine serum albumin and completely reduced bovine serum albumin in the presence of urea. Proc Natl Acad Sci USA 72, 2044-8.

17. Mader P, Kolthoff IM, Vesela V. (1982) Catalytic hydrogen activity of the low-molecular weight thiols - kinetic control of the Brdicka catalytic current. Electrochim Acta 27, 1393-401.

18. Heyrovsky M. (2000) New aspects of the Brdicka reaction of low-molecular thiols; Voltammetry at low rate of potential scan. Electroanalysis 12, 935-9.

19. Erk M, Ivanković D, Raspor B, Pavičić J. (2002) Evaluation of different purification procedures for the electrochemical quantification of mussel metallothioneins. Talanta 57, 1211-8.

20. Petrlova J, Potesil D, Mikelova R, Blastik O, Adam V, Trnkova L, Jelen F, Prusa R, Kukacka J, Kizek R. (2005) Attomole voltammetric determination of metallothionein. Electrochim Acta submitted.

21. Kalous V. (2004) 70 let od objevu Brdičkovy polarografické reakce bílkovin. Klin. Biochem. Metab. 12, 265-7.

22. Brdicka R. (1937) Polarographic investigation in serological cancer diagnosis. Nature 139, 1020-1.

23. Brdicka R. (1937) Application of the polarographic effect of proteins in cancer diagnosis. Nature $139,330$.

24. Adam V, Zehnalek J, Petrlova J, Potesil D, Sures B, Trnkova L, Jelen F, Vitecek J, Kizek R. (2005) Phytochelatin modified electrode surface as a sensitive heavy-metal ion biosensor. Sensors 5 , 70-84.

25. Palecek E, Postbieglova I. (1986) Adsorptive stripping voltammetry of biomacromolecules with transfer of the adsorbed layer. $\mathbf{J}$ Electroanal Chem 214, 359-71.

26. Palecek E, Jelen F, Postbieglova I. (1989) Adsorptive transfer stripping voltammetry offers new possiblities in DNA research. Stud Biophys 130, 51-4.

27. Kizek R, Vacek J, Trnková L, Klejdus B, Havel L. (2004) Application of catalytic reactions on a mercury electrode for metallothionein electrochemical detection. Chem Listy 98, 160-7.

28. Zelená J, Potešil D, Vacek J, Adam V, Hradecký J, Prusa R, Kizek R, Vojtěšek B. (2004) Metalothionein jako prognostický marker nádorového onemocnění. Klinická onkologie 17, 190-5.

29. Kizek R, Vacek J, Adam V, Vojtěšek B. (2004) Vztah metalothioneinu k rakovině a protinádorové léčbě. Klin Biochem Metab 12, 72-8. 